\title{
Gesture Production in a Story Recalling Task of Preschool Children with Specific Language Impairment
}

\author{
Eun-Young Kim, Hee-Ran Lee \\ Department of Speech and Hearing Therapy, Catholic University of Pusan, Busan, Korea
}

Correspondence: Hee-Ran Lee, $\mathrm{PhD}$ Department of Speech and Hearing Therapy, Catholic University of Pusan, 57 Oryundae-ro, Geumjeong-gu, Busan 46252, Korea Tel: $+82-51-510-0841$

Fax: +82-51-510-0848

E-mail: hrlee@cup.ac.kr

Received: April 5, 2021

Revised: May 6, 2021

Accepted: May 13, 2021

This work is based on the master's thesis of the first author.

\begin{abstract}
Objectives: The purpose of this study was to investigate the gesture production characteristics of Korean preschool children with specific language impairment (SLI) through the task of recalling a story after seeing a wordless-cartoon. Methods: The subjects of this study were sixteen children aged 5-6 years with SLI, 16 children with typical development (TD) matched by their chronological age (CA) and 16 children with typical development matched by their language age (LA). To compare gesture production characteristics of Children with SLI, wordless-cartoons and 5 facilitative questions were used. Results: First, there were significant differences between the SLI group and CA matched group in deictic gesture and representational gesture. However, there was no significant the difference in conventional gesture. Second, as a result of examining difference in proportion by modality of expression among those groups, there were significant differences between the SLI group and the CA matched group in spoken language and coverbal gesture. Third, there was no significant difference in the concordance rate of coverbal gesture. Conclusion: Children with SLI were found to produce gestures at a higher frequency than TD children, but there was no difference in the concordance rate of coverbal gestures. Thus, this study suggest that intervention is necessary to induce children with SLI to use spoken language and gestures together in order to effectively improve their expressive language ability.
\end{abstract}

Keywords: Specific language impairment, Gesture, Coverbal gesture
우리는 다른 사람과 상호작용을 하기 위해 다양한 의사소통 양 식을 사용한다. 자신의 생각과 감정을 전달할 때 대체로 말과 글이 라는 언어 양식을 사용하지만 얼굴 표정이나 행동 또는 제스처 등 의 비언어적 양식으로 전달하기도 한다.

비언어적 양식 중 하나인 제스처는 상징적인 표현을 위해 상체 앞 공간에서 나타나는 손과 팔의 움직임으로 정의된다(McNeill, 1998). 언어 이전(prelinguistic) 시기의 영유아는 아직 구어를 사용 하여 의사소통을 하지 못하기 때문에 제스처에 의존하여 자신의 의도를 표현한다. 영유아들은 구어로 표현하기 전부터 제스처를 사용하기 시작하고 제스처는 타인과 상호작용을 할 수 있는 중요 한 수단일 뿐 아니라 의사소통을 촉진하는 작용을 하기 때문에 언 어 습득과 발달 영역에서 중요하다(Guidetti \& Colletta, 2010). 일
부 연구자들은 가리키기(pointing)의 유무 또는 빈도가 언어발달 지체에 대한 초기 지표가 될 수도 있음을 밝히고 있다(Lueke, Ritterfeld, Grimminger, Liszkowski, \& Rohlfing, 2017; Esseily, Jacquet, \& Fagard, 2011).

특히, 제스처는 한국판 맥아더-베이츠 의사소통발달 평가(Korean MacArthur-Bates Communicative Development Inventories, K M-B CDI; Pae \& Kwak, 2011)나 의사소통 및 상징행동 척도(Communication and Symbolic Behavior Scales Development Profile, CSBS DP; Wetherby \& Prizant, 2002) 같은 언어 평가 도구의 주요 세부 항목이며, 자폐범주성장애 아동의 진단 기준에서도 사회적 상호작용을 위한 비언어적 의사소통 행동 결함의 대표적인 예로 언급되며 이해와 사용에서의 결함 여부가 중요한 발달적 지표가 되 
고 있다.

제스처의 유형 분류에 대해 살펴보면, Capirci, Iverson, Pizzuto 와 Volterra (1996)는 제스처를 지시적(deictic) 제스처, 표상적(representational) 제스처로 분류하였다. 또한, 지시적 제스처를 손가락 으로 대상을 가리키는 가리키기와 원하는 대상을 향해 손을 뻗거 나 성인의 관심을 얻기 위해 대상을 보여주는 도구적(instrumental) 제스처로 세분화하였으며, 표상적 제스처는 '아니’의 의미로 고 개를 젓는 관습적(conventional) 제스처와 대상의 형태나움직임을 손이나 몸으로 표현하는 도상적(iconic) 제스처로 나누었다. 이와 달리 Iverson, Capirci, Longobardi와 Caseli (1999)는 지시적, 관습 적, 표상적 제스처의 세 범주로 제스처 유형을 나누었다. 각 범주별 로 지시적 제스처에는 주기, 보여주기, 가리키기가 포함되며, 관습 적 제스처에는 손 흔들며 인사하기, 고개 젓기, 고개 끄덕이기가 포 함되어 있고 표상적 제스처는 양치하기, 머리 빗기, 음식 먹기와 같 은 것들이 포함된다. 가장 최근의 분류로 So, Wong, Lui와 Yip (2015) 은 기존의 지시적, 도상적 제스처에 더해 문화적으로 특정한 의미 를 표현하는 제스처를 추가하였다. 이들은 문화적 의미를 나타내 는 제스처가 기존의 관습적 제스처로 분류되었음에도 제스처보다 는 표지(marker)로 분석하는 특이성을 보이고 있다. 이에 더해 의미 적 내용을 담고 있지는 않지만 수반하는 구어의 독특한 리듬을 따 르는 비트(beat) 제스처를 분류함으로써 구어 특성을 반영하여 보 다 풍부하고 세분화된 제스처 유형 분석들을 제언하였다.

제스처의 유형과 관련된 국내 연구에서 $\operatorname{Kim}(2006)$ 은 지시적, 관습적, 표상적으로 제스처를 분류하고 있다. 반면, Park (2009)은 지시적, 표상적 제스처 분류는 이전 연구자와 동일하게 분류하였지 만, 표상적 제스처를 참조적 제스처와 관습적 제스처로 분류함으 로써 제스처 유형을 보다 세분화하고 있다. 이러한 분류체계는 An (2010)의 연구에서 보다 세분화되는데, 지시적 제스처는 도구적 제 스처와 지적하기로 세분하였고, 표상적 제스처는 관습적 제스처와 참조적 제스처로 세분하였다. An, Bang과 Lee (2010)는 An (2010) 과 제스처 유형 분류체계를 동일하게 사용했으나 참조적 제스처라 는 용어 대신 도상적 제스처라는 용어를 사용하였다. 이렇듯 연구 자들마다 제스처의 유형 분류에 차이가 있지만 Iverson 등(1999)이 제시한 지시적, 관습적, 표상적 분류 기준이 제스처 발달 연구에서 가장 많이 활용되고 있었다(Kim \& Kim 2006; Lee, Jeon, \& Lee, 2014; Lee \& Lee, 2015; Shin \& Kim, 2016).

제스처에 대한 관심은 고대에서부터 살펴볼 수 있는데 그리스와 로마를 비롯한 서구의 전통에서 제스처는 담화의 목적을 아주 강 력하고 설득력 있게 효과적으로 달성하기 위한 표현 자질로 인식되 었다고 한다(Kendon, 2004). 일반적으로 영유아들은 언어발달의
초기부터 제스처를 사용하여 의사소통을 하게 되는데, 이러한 제 스처는 영유아 시기뿐만 아니라 성인에 이르기까지 의사소통에서 중요한 기능을 한다. 제스처는 자신의 내적 사고과정을 촉진하여 다른 사람과 상호작용을 원활하게 수행하기 위한 기능과 자신의 생각을 외형화하여 다른 사람과의 상호작용을 촉진시키기 위한 기 능이 있다(Hadar \& Pinchas-Zamir, 2004; as cited in Lozano \& Tversky, 2006). 또한, 제스처를 사용하는 것은 말로 정보를 전달하 는 것보다 더 효율적이고 유용한 의사소통 수단이 되기도 한다 (Ryu \& Yu, 2013). 이처럼 제스처가 의사소통을 촉진하는 역할을 한다는 입장이 있는 반면, 언어 능력이 낮은 아동의 경우 낮은 언어 능력을 보상하기 위해 제스처를 더 많이 사용할 수도 있다는 주장 (Evans, Alibali, \& McNeil, 2001)과 구어 표현에 어려움이 있을 때 제스처가 더 많아질 것(Bangerter, 2004; De Ruiter, 2006; Van der Sluis \& Krahmer, 2007)이라는 주장도 있다.

제스처는 첫 낱말 시기 아기에게는 구어로 표현되지 못한 정보나 단어를 대체하여 표현할 수 있는 수단이 되기도 한다. 아기가 가장 먼저 사용하는 가리키기나 주기, 보여주기 같은 지시적 제스처는 언어 이전 시기에 출현하므로 무엇보다 의사소통적 의도를 전달하 기 위한 화용적 기능을 지닌다. 즉, 참조 대상에 대한 주의 끌기와 요청하기를 비롯해 성인과의 상호작용을 유지하거나 얻기 위한 수 단이 된다. 아기들은 12 개월경 의미 있는 첫 낱말을 산출하게 되지 만, 첫 낱말 산출 후에도 지속해서 제스처를 사용한다. 이때 나타나 는 도상적 제스처는 참조 대상의 형태, 움직임, 기능, 공간 관계 등 을 전달하는 중요한 기능을 하며 아기 손말(baby sign)로 불리기도 한다(Acredolo \& Coodwyn, 1996). 아기들은 월령이 증가할수록 구어 표현과 제스처를 결합하여 사용하며, 16-18개월경에는 표현 하고자 하는 의미를 보충하기 위하여 낱말과 제스처를 결합하여 사용하게 되는데(Morford \& Goldin-Meadow, 1992) 직접적인 의 사 표현보다는 구어 표현의 보조적인 역할을 하기도 한다(Kim, 2006; Park, 2009). 즉, 두 낱말을 조합하여 산출하기 전에 아기는 제 스처를 사용하여 부족한 언어 표현을 보충하거나 대체하며, 이러 한 과정을 통해 낱말을 빠르게 학습할 뿐 아니라 두 낱말 조합의 기 반을 마련한다(Lee \& Lee, 2012; Wetherby \& Prizant, 1989).

구어의 보조적인 기능을 하는 제스처는 언어이전단계의 일반 영 유아들뿐만 아니라 의사소통에 어려움이 있는 장애 아동에게도 나타난다. 제스처가 의도를 표현하기 위한 의사소통 보조 수단이 되기도 하므로, 때로는 특정 장애군의 아동에게는 언어 중재의 목 표가 될 수 있다. 많은 연구자들은 의사소통에 어려움이 있는 언어 장애 아동들인 언어발달지체, 자폐범주성장애, 다운증후군 아동 대상의 제스처 연구를 진행하며, 제스처가 이들 아동들의 의사소 
통 특성을 규명 짓는 중요한 연구과제임을 밝히고 있다(Kim \& Ko, 2002; Kim, 2014; Leonard, 2014; Wetherby \& Prutting, 1984). 전반 적인 언어발달 영역에서 어려움을 보이는 언어발달지체 아동들은 자신의 의도를 표현하는 데 어려움이 있기 때문에 비구어적인 제 스처를 더 많이 사용하는 경향이 있다고 한다(Kim, 2014; Leon$\mathrm{ard}, 2014)$. 또한, 언어이전단계와 언어발달 초기단계의 자폐범주성 장애 아동은 자신의 의사를 표현하기 위해 발성보다는 제스처를 더 빈번하게 사용한다고 보고하였다(Wetherby \& Prutting, 1984). 이렇듯 제스처는 장애아동들의 부족한 의사소통 능력을 보조하 는 역할로 사용될 수 있으며, 의사소통을 위한 주요 표현 수단이 될 있다. 하지만 특정 장애 유형, 예를 들어 자폐범주성장애 아동의 경 우에는 단순히 제스처 사용 빈도만이 아닌 유형에서 차이를 보이 며, 이러한 차이는 사회의사소통 특성과 관련이 될 수도 있을 것이 므로 제스처가 의사소통 능력을 보조하는 수단이라 결론짓기에는 어려움이 있을 것이다.

한편, 언어 영역에서 결함을 보이는 단순언어장애 아동은 첫 낱 말 산출부터 지연되어 구어 표현에 어려움을 보이고, 적절한 낱말 찾기의 어려움으로 또래 일반 아동에 비해 제스처를 사용하는 경 우가 많다(Blake, Myszczyszyn, Jokel, \& Bebiroglu, 2008; Weismer \& Hesketh, 1993; Lavelli, Barachetti, \& Florit, 2015; Lavelli \& Majorano, 2016; Mainela-Arnold, Alibali, Hostetter, \& Evans, 2014).

단순언어장애 아동의 제스처 사용에 관한 연구에서 Blake 등 (2008)은 이들이 일반 아동보다 도상적 제스처를 더 많이 산출하였 고, 단어들을 대체하기 위해 제스처를 더 빈번하게 사용한다고 보 고하였다. Ellis Weismer와 Hesketh (1993)의 연구에서도 단순언어 장애 아동들은 자신의 구어에 없는 정보를 제스처로 표현하는 경 우가 더 많았으며, 구어와 제스처가 결합된 경우 구어만 표현할 때 보다 더 많은 정보를 표현한다고 보고하였다. Lavelli 등(2015)은 책 읽기 과제를 통해 단순언어장애 아동과 일반 아동의 제스처 사용 을 연구하였다. 이들의 연구에서는 단순언어장애 아동이 일반 아 동보다 더 많은 제스처를 사용했으며, 단순언어장애 아동에게서 구어동반 제스처의 비율이 유의하게 높았다고 보고하였다. 또한 Lavelli와 Majorano (2016)는 학령전 3-5세의 단순언어장애 아동 과 일반 아동(생활연령일치 집단, 언어연령일치 집단)이 그림 카드 를 보고 이름대기 과제를 수행하는 동안에 산출한 구어 표현의 정 확성, 표현양식 유형(modality of expression), 제스처 유형, 그리고 제스처와 구어의 의미적 관계의 차이를 비교하였다. 이 연구에서 단순언어장애 아동은 일반 아동보다 구어와 제스처를 함께 사용 하는 다중양식(bimodal) 비율이 높았으며, 단순언어장애 아동들 은 구어 표현의 발판화(scaffolding)를 위해 제스처에 의존하고 있
다고 제언하였다.

반면, 일부 연구는 단순언어장애 아동들이 일반 아동들보다 더 자주 제스처를 산출하지는 않는다는 것을 보고하였다. Evans 등 (2001)은 7-9세의 단순언어장애 아동들이 피아제 보존 개념 실험에 대한 설명을 하는 동안의 제스처 사용을 연구한 결과, 이들이 일반 아동과 비슷한 비율로 제스처를 산출했으나, 발화에 없는 정보를 제스처로 표현하는 경우가 많았음을 확인하였다. 또한 구어만 사 용할 때보다 구어와 제스처가 결합된 경우 설명해야 할 과제의 내 용에 관한 더 발전된 지식을 표현했음을 보고하였다. 이처럼 단순 언어장애 아동들은 자신들의 표현 언어 능력의 결함을 보상하기 위해 제스처를 사용하는 것으로 볼수 있다.

이상에서 살펴본 바와 같이, 제스처는 일반 영유아뿐 아니라 언 어 습득에 결함이 있는 아동들에게서도 언어와 의사소통 발달의 특징을 살펴볼 수 있는 중요한 소통 기제가 될 수 있다. 특히, 전형적 으로 발달하는 아동들과 비교해 차이가 없는 인지 능력에도 불구 하고, 질적으로 다른 언어발달 특성을 보이는 단순언어장애 아동 에게서 이러한 제스처 발달 특성을 살펴본다면 이들의 언어 중재 를 위한 매우 중요한 임상적 시사점을 제시해 줄수 있을 것이다.

Mainela-Arnold 등(2014)은 무발화 만화 영상을 보고 이야기를 회상하여 말하는 과제를 통해 단순언어장애 아동과 일반 아동의 표상적 제스처 산출 빈도 차이, 구어와 제스처 조합(speech-gesture combination)의 일치율 차이를 비교하여 단순언어장애 아동들이 일반 아동보다 더 많은 제스처를 산출하였지만 일치율에서 일반 아동과 크게 다르지 않다고 보고하였다. 하지만, 구어 표현에 점차 익숙해지게 되면서 아동의 제스처 역시 정교성을 더해가며 이와 더 불어 구어와 제스처를 조합하여 사용하는 능력도 발달해가게 될 것이므로, 일치성이라는 측정치에 더해 전반적인 표현양식에서 제 스처가 차지하는 비율과 제스처 유형에 대한 분석은 단순언어장애 아동의 표현 특성을 밝히는 데 중요하게 작용하게 될 것이다.

따라서, 본 연구에서는 Mainela-Arnold 등(2014)의 제스처 유도 절차를 참조하여 5-6세 단순언어장애 아동이 산출하는 제스처를 유형별로 나누어 분석하고, 의도 표현양식 유형(구어, 제스처, 구어 동반 제스처)의 비율에 더해 구어와 동반하는 제스처의 일치율을 함께 살펴보고자 한다.

\section{연구방법}

\section{연구대상}

본 연구의 대상은 5-6세 단순언어장애 아동 16명, 생활연령을 일 치시킨 일반 아동 16 명, 언어연령을 일치시킨 일반 아동 16 명을 대 
상으로 하였다.

단순언어장애 집단은 Leonard (2014)의 기준에 따라 다음과 같 이 선정하였다. (1) 취학 전 아동의 수용언어 및 표현언어 발달 척도 (Preschool Receptive-Expressive Language Scale, PRES; Kim, Sung, \& Lee, 2003) 결과, 수용언어와 표현언어 모두 생활연령에 비해 $10 \%$ ile 이하에 속하고, (2) 카우프만 아동용 지능검사(Korean Kaufman Assessment Battery for Children, K-ABC; Moon \& Byun, 2003) 결 과, 비언어성 지능이 85점 이상이며, (3) 부모나 교사에 의해 시각 및 청각과 같은 감각 장애와 기타 신경학적 질환, 사회적 상호작용 능력에 심각한 결함이 없는 아동으로 선정하였다.

생활연령일치 집단은 (1) 취학 전 아동의 수용언어 및 표현언어 발달 척도(PRES; Kim et al., 2003) 결과, 통합언어연령이 생활연령 에 비해 $10 \%$ ile 이상에 속하고, (2) 카우프만 아동용 지능검사(K$\mathrm{ABC}$; Moon \& Byun, 2003) 결과, 비언어성 지능이 85점 이상이며, (3) 부모나 교사에 의하여 언어 및 기타 발달에서 문제가 없는 것으 로 보고되고, (4) 단순언어장애 아동 집단의 평균 생활연령 \pm 3 개 월 이내에 해당하는 아동들로 선정하였다.

언어연령일치 집단은 (1) 취학 전 아동의 수용언어 및 표현언어 발달 척도(PRES; Kim et al., 2003) 결과, 단순언어장애 집단과 통합 언어연령이 \pm 3 개월 이내에 속하며, (2) 카우프만 아동용 지능검사 (K-ABC; Mun \& Byun, 2003) 결과, 비언어성 지능이 85점 이상이 며, (3) 부모나 교사에 의하여 언어 및 그 외 발달에서 문제가 없는 것으로 보고된 아동들로 선정하였다. 대상자에 대한 정보는 Table 1 과같다.

단순언어장애 집단의 생활연령은 평균 5세 11 개월(5세 2개월-6세 6 개월)이었으며, 생활연령일치 집단의 생활연령도 평균 5 세 11 개월 (5세 3개월-6세 6개월)이었다. 집단 간 $t$-검정을 실시한 결과, 집단간 생활연령에 따른 유의한 차이가 나타나지 않았다 $(t=-.32, p>.05)$. 또한 단순언어장애 집단의 언어연령은 평균 4 세 10 개월(4세 2 개 월-5세 3 개월)이었으며, 언어연령일치 집단의 언어연령도 평균 4세 10 개월(4세 2 개월-5세 6 개월)이었다. 집단 간 $t$-검정을 실시한 결과,

Table 1. Characteristics of participants

\begin{tabular}{lccc}
\hline & SLI group (N=16) & CA group (N=16) & LA group (N=16) \\
\hline Age (mo) & $71.38(4.90)$ & $71.94(5.13)$ & $63.63(3.32)$ \\
Language age $^{\mathrm{a}}$ & $58.63(4.73)$ & $68.81(4.55)$ & $58.81(4.54)$ \\
Nonverbal IO $^{\mathrm{b}}$ & $106.38(12.18)$ & $119.25(8.83)$ & $114.06(13.50)$ \\
\hline
\end{tabular}

Values are presented as mean (SD).

$S L I=$ children with specific language impairment; $C A=$ chronological age-matched children; LA= language age-matched children.

aPreschool Receptive-Expressive Language Scale (Kim, Sung, \& Lee, 2003), 'KKorean Kaufman Assessment Battery for Children (Moon \& Byun, 2003).
단순언어장애 집단과 언어연령일치 집단 간 언어연령에 따른 유의 한 차이가 나타나지 않았다 $(t=-.11, p>.05)$.

본 연구는 부산가톨릭대학교 기관생명윤리위원회(Institute Review Board, IRB)의 승인을 받았다(승인번호: CUPIRB-2019-025).

\section{연구도구}

무발화 만화 영상

본 연구에서 사용한 무발화 만화(wordless-cartoon) 영상은 등 장 주인공과 배경음은 있지만 주인공들 사이에 어떠한 구어적 표현 이 없는 영상으로, 아동이 무발화 만화 영상을 보고 난 후 영상의 내용을 회상하여 이야기하는 과제에서 산출하는 제스처의 특성을 보기 위한 도구이다.

연구에서 사용된 무발화 만화 영상은 선행연구(Alibali, Evans, Hostetter, Ryan, \& Mainela-Arnold, 2009; Mainela-Arnold et al., 2014)에서 사용한 독일의 어린이 만화인 'Die Sendung mit der Maus (생쥐와 함께 하는 프로그램)'의 시리즈 중에서 선정한 에피소드로 영상의 길이는 37 초 정도이다.

본 연구에서 사용한 무발화 영상은 움직이는 시각 정보로 입력 이 제공되어 아동의 집중도 향상과 흥미를 이끌 수 있다. 무발화 영 상 내용은 작은 코끼리와 큰 쥐가 등장하며, 배경 음악은 있지만 주 인공인 큰 쥐와작은 코끼리가 서로 주고받는 말은 없다. 만화의 내 용은 해가 내려쬐는 더운 날씨에 큰 쥐와 작은 코끼리가 땀을 흘리 며 해변가를 걸어가다가 조개를 발견한다. 조개를 발견한 큰 쥐와 작은 코끼리는 조개 앞에 멈춰 서고, 큰 쥐는 손으로 조개를 만지더 니 쩝쩝거리며 혀를 날름거린다. 큰 쥐는 조개를 열려고 조개를 쿵 쿵 두드리고 위로 힘껏 당겨보지만 꿈쩍도 하지 않자 발로 조개를 쿵쿵 밟는다. 마침내 조개 틈이 벌어지고 작은 코끼리는 코로 조개 껍질을 들어 올린다. 큰 쥐와작은 코끼리는 함께 열린 조개 안을 살 폈지만 아무것도 들어있지 않다. 그러자 큰 쥐는 조개껍질을 머리 위로 번쩍 들어 올리고, 작은 코끼리도 코로 조개껍질을 들어 올려 머리에 쓰지만 조개가 너무 커서 눈을 가린다. 작은 코끼리가 조개 껍질을 머리에 쓴 채로 걸어가는 것을 끝으로 만화가 마무리된다. 연구에서 사용한 무발화 만화 영상 장면의 예시는 Appendix 1에 제시하였다.

\section{촉진 질문}

검사자는 아동이 만화 내용에 대한 이야기를 끝마칠 때까지 기 다린 후 아동이 만화 내용에 대한 이야기를 조금 더 할 수 있도록 촉 진하는 질문 5 개를 모든 아동들에게 공통적으로 제시하고 답하게 하였다. 연구에서 사용한 촉진 질문은 Appendix 2에 제시하였다. 


\section{내용 타당도}

아동에게 제시되는 무발화 만화 영상과 촉진 질문이 아동의 제 스처 산출을 살펴보기 위한 도구로 적합한지에 대한 내용 타당도 를 검증하기 위해 3 명의 전문가에게 내용 타당도에 관한 검증을 받 았다. 전문가 3 명은 모두 언어재활사 1 급 자격증과 언어병리학 박사 학위를 소지하였다. 3 명의 전문가는 이야기 회상 과제에서 사용되 는 무발화 만화 영상과 아동의 반응을 유도하기 위한 촉진 질문에 대한 타당도를 Likert 5 점 척도 $(1=$ 매우 부적절, $2=$ 부적절, $3=$ 보 통, $4=$ 적절, $5=$ 매우 적절)로 평가하였으며, 그 결과 무발화 만화 영상 타당도는 4.67점, 촉진 질문 타당도는 4.67점으로 나타났다. 내용 타당도 평가 결과, 전문가의 의견을 반영하여 촉진 질문 문장 에 사용된 어휘 가운데 '설명'을 '이야기'로 수정하거나 촉진 질문 문장에 중복된 어휘를 제외하여 사용하였다. 촉진 질문은 2 차에 걸쳐 수정하였고, 위 3 명의 전문가 중 1 명과 함께 2 차 수정을 진행 하였다.

\section{연구절차}

본 연구는 검사자가 아동의 유치원과 어린이집을 방문하여 실시 하였고, 소음의 영향을 최소화하기 위해 검사자와 아동이 작은 교 실에서 1:1로 진행하였다. 연구에서 무발화 만화 영상은 노트북 화 면을 통해 제시하였으며 각 아동에게 영상을 두 번 보여주었다. 이 야기 회상 과제를 진행하기 전에 검사자와 아동은 책상에 마주 앉 고 검사자는 아동에게 “선생님이 만화를 두 번 보여줄 거야. 그러면 $\bigcirc \bigcirc$ 이가 만화를 다 보고 난 후에 선생님한테 만화 내용을 이야기 해 주면 돼.”라고 연구 절차에 대해 설명하였다. 다음으로 검사자는 아동에게 무발화 만화 영상을 두 번 보여주고 “자, 만화를 두 번 봤 어. 이제 선생님한테 만화 내용을 이야기해 줄래?”라고 아동에게 말해주었다. 그리고 검사자는 아동이 만화 내용에 대한 이야기를 끝마칠 때까지 기다린 후 아동이 만화 내용에 대한 이야기를 조금 더 할 수 있도록 촉진하는 촉진 질문 5 개를 제시하였다. 본 연구에 소요된 시간은 5 분 정도였다.

\section{자료분석}

본 연구의 모든 분석 자료는 아동이 제시된 영상을 보고 이야기 를 회상하여 말하는 과정을 녹화한 후 전사하여 분석하였다. 본 연 구에서는 제스처 분류에 대한 기준이 명료하며 국내 제스처 연구 에서 가장 많이 활용되고 있는 Iverson 등(1999)이 제시한 분류 기 준을 참고하여 연구자가 수정한 조작적 정의에 따라 제스처 유형을 분석하였다(Appendix 3). 제스처 유형별 빈도는 아동이 산출한 총 제스처를 지시적, 관습적, 표상적 제스처로 분류하여 분석하였다.
그리고 표현양식 유형 비율(\%)은 먼저, 아동이 산출한 제스처, 구어, 구어동반 제스처의 빈도를 각각 구하였다. 제스처는 구어 표 현 없이 제스처로만 표현했을 경우 제스처로 분류하였으며, 구어는 제스처 표현 없이 구어로만 표현했을 경우 구어로 분류하였다. 그 리고 구어동반 제스처는 구어와 제스처가 동반했을 경우 구어동 반 제스처로 분류하였다. 제스처, 구어, 구어동반 제스처는 문장 종 결을 기준으로 발화를 나누어 분석하였다. 다음으로 분모는 제스 처와 구어 그리고 구어동반 제스처의 총합으로 하고, 아동이 산출 한 제스처, 구어 혹은 구어동반 제스처를 각각 분자로 나눈 다음 100 을 곱해서 산출하였다.

마지막으로 구어동반 제스처 일치율(\%)은 아동이 구어로 표현 한 정보와 제스처로 표현한 정보가 일치하는지를 알아보기 위해 아동이 산출한 구어동반 제스처 중에서 구어 정보와 제스처 정보 가 일치하는 경우를 분석하였다. 예를 들어 아동이 조개라고 말하 면서 조개의 크기나 상태를 표현하는 제스처를 표현했을 경우 구 어 정보와 제스처 정보가 일치하는 것으로 분석하였다.

\section{신뢰도}

본 연구의 이야기 회상 과제에서 나타난 제스처 유형별 산출 빈 도와 표현양식 유형 비율, 그리고 구어동반 제스처 일치율을 분석 한 후 분석 신뢰도를 검증하기 위해 분석자 간 신뢰도를 산출하였 다. 분석자 간 신뢰도는 언어병리학 석사 학위 소지자 2 명에게 검사 절차와 기록 및 분석 방법을 상세하게 설명한 후 수집된 전체 자료 의 $30 \%$ 를 임의로 선정하여 분석하도록 하였다. 그 결과 제스처 유 형별 산출 빈도, 표현양식 유형 비율, 구어동반 제스처 일치율의 신 뢰도는 각 $96.20 \%, 95.55 \%, 90 \%$ 였다.

\section{통계처리}

본 연구에서는 학령전 단순언어장애 아동이 무발화 만화 영상 을 보고 이야기를 회상하여 말하는 동안에 나타난 제스처 유형별 산출 빈도와 표현양식 유형 비율의 차이, 그리고 구어동반 제스처 일치율을 일반 아동과 비교하여 살펴보고자 하였다. 이를 위해 IBM SPSS Statistics 25 프로그램을 사용하여 일원분산분석(One-way $\mathrm{ANOVA)}$ 을 실시하였다. 이후 집단 간 차이가 어느 집단 간의 차이 인지 알아보기 위해 Scheffé 사후 검정을 실시하였다.

\section{연구결과}

\section{집단 간 제스처 유형별 산출 빈도}

집단 간 제스처 유형별 산출 빈도 차이를 비교한 결과, 단순언어 
장애 집단과 언어연령일치 집단의 제스처 유형별 산출 빈도는 표상 적, 지시적, 관습적 제스처 순이었다. 반면에 생활연령일치 집단은 표상적 제스처가 가장 높았고 지시적 제스처와 관습적 제스처는 동일한 산출 빈도를 보였다(Figure 1). 집단 간 총 제스처 산출 빈도 를 비교했을 때, 단순언어장애 집단이 두 일반 아동 집단보다 높은 제스처 산출 빈도를 보였다. 제스처 산출 빈도는 단순언어장애 집 단, 언어연령일치 집단, 생활연령일치 집단 순이었다.

집단 간 제스처 유형별 산출 빈도 차이가 통계적으로 유의미한 지 알아보기 위해 일원분산분석을 실시한 결과, 지시적 제스처에서 집단 간의 차이가 통계적으로 유의미하였다 $\left(F_{(2,45)}=3.626, p<.05\right)$. 또한 표상적 제스처에서도 집단 간 차이가 유의미하게 나타났다 $\left(F_{(2,45)}=3.293, p<.05\right)$. 반면 관습적 제스처에서는 집단 간 차이가 유의미하지 않았다 $\left(F_{(2,45)}=.207, p>.05\right)$.

집단 간 차이를 자세하게 알아보기 위해 Scheffé 사후분석을 실 시한 결과, 지시적 제스처와 표상적 제스처에서 단순언어장애 집단 이 생활연령일치 집단 $(p<.05)$ 보다 유의미하게 높은 것으로 나타

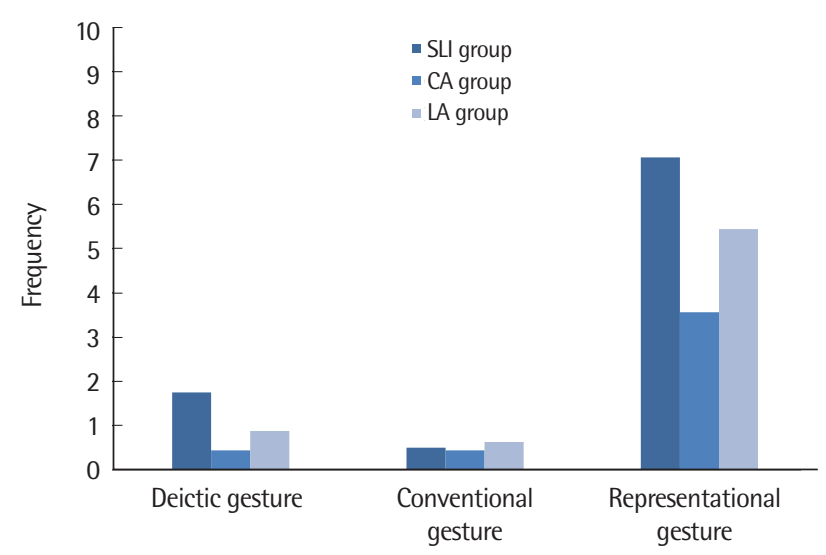

Figure 1. Difference in frequency of production by gestures types among those groups.

$\mathrm{SLI}=$ children with specific language impairment; $\mathrm{CA}=$ chronological age-matched children; $L A=$ language age-matched children.

Table 2. Comparison of difference in frequency of production by gesture types among those groups

\begin{tabular}{lcccc}
\hline & $\begin{array}{c}\text { SLI group } \\
(\mathrm{N}=16)\end{array}$ & $\begin{array}{c}\text { CA group } \\
(\mathrm{N}=16)\end{array}$ & $\begin{array}{c}\text { LA group } \\
(\mathrm{N}=16)\end{array}$ & $F$ \\
\hline Deictic gesture & $1.75(1.92)$ & $0.44(1.09)$ & $0.88(1.03)$ & $3.626^{*}$ \\
Conventional gesture & $0.5(0.63)$ & $0.44(0.81)$ & $0.63(1.03)$ & .207 \\
Representational gesture & $7.06(4.31)$ & $3.56(3.50)$ & $5.44(3.72)$ & $3.293^{*}$ \\
\hline
\end{tabular}

Values are presented as mean (SD).

$S L I=$ children with specific language impairment; $C A=$ chronological age-matched children; $\mathrm{LA}=$ language age-matched children. ${ }^{*} p<.05$.
났다. 하지만 관습적 제스처에서는 집단 간 유의미한 차이가 나타 나지 않았다(Table 2).

\section{집단 간 표현양식 유형 비율}

세 집단 간 표현양식 유형 비율의 차이를 비교한 결과, 먼저 단순 언어장애 집단의 경우, 제스처는 평균 $.86(\mathrm{SD}=2.36)$, 구어는 평균 $37.75(\mathrm{SD}=21.63)$, 구어동반 제스처는 평균 $61.38(\mathrm{SD}=22.70)$ 이었 다. 생활연령일치 집단의 경우에는 제스처는 평균 $.39(\mathrm{SD}=1.56)$, 구어는 평균 $72.39(\mathrm{SD}=24.75)$, 구어동반 제스처는 평균 $27.22(\mathrm{SD}=$ 24.42)이었다. 마지막으로 언어연령일치 집단을 살펴보면, 제스처 는 평균 $1.22(\mathrm{SD}=3.36)$, 구어는 평균 $58.89(\mathrm{SD}=23.18)$, 구어동반 제스처는 평균 $39.90(\mathrm{SD}=21.84)$ 이었다. 요약하자면, 단순언어장 애 집단은 구어동반 제스처의 비율이 가장 높았으나 이와 달리 생 활연령일치 집단과 언어연령일치 집단은 구어의 비율이 높았다 (Figure 2).

집단 간 표현양식 유형 비율의 차이가 통계적으로 유의미한가를 알아보기 위해 일원분산분석을 실시하였다. 일원분산분석 결과, 구어에서 집단 간의 차이가 통계적으로 유의미하였다 $\left(F_{(2,45)}=9.045\right.$, $p<.05)$. 또한 구어동반 제스처에서도 집단 간의 차이가 유의미하 게 나타났다 $\left(F_{(2,45)}=3.293, p<.05\right)$. 반면 제스처에서는 집단 간 차 이가 유의미하지 않았다 $\left(F_{(2,45)}=.426, p>.05\right)$.

집단 간 차이를 자세하게 살펴보기 위해 Scheffé 사후분석을 실 시한 결과, 구어와 구어동반 제스처에서 단순언어장애 집단과 생 활연령일치 집단 $(p<.01)$, 단순언어장애 집단과 언어연령일치 집단 $(p<.05)$ 사이에서 유의한 차이가 나타났다. 하지만 제스처에서는 세 집단 간 유의미한 차이가 나타나지 않았다(Table 3).

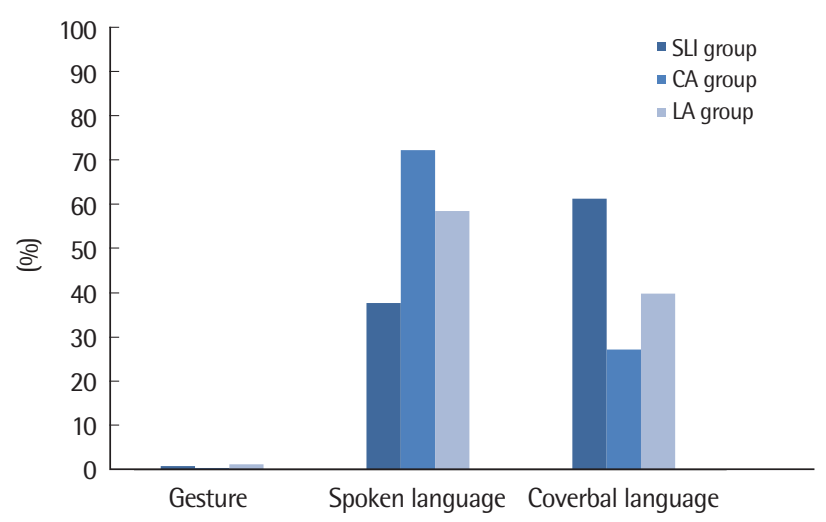

Figure 2. Difference in proportion by modality of expression among those groups.

$\mathrm{SLI}=$ children with specific language impairment; $C A=$ chronological agematched children; $L A=$ language age-matched children. 
Table 3. Comparison of difference in proportion by modality of expression among those groups

\begin{tabular}{lcccc}
\hline & $\begin{array}{c}\text { SLI group } \\
(\mathrm{N}=16)\end{array}$ & $\begin{array}{c}\text { CA group } \\
(\mathrm{N}=16)\end{array}$ & $\begin{array}{c}\text { LA group } \\
(\mathrm{N}=16)\end{array}$ & $F$ \\
\hline Gesture & $.86(2.36)$ & $.39(1.56)$ & $1.22(3.36)$ & .426 \\
Spoken language & $37.75(21.63)$ & $72.39(24.75)$ & $58.89(23.18)$ & $9.045^{*}$ \\
Coverbal language & $61.38(22.70)$ & $27.22(24.42)$ & $39.90(21.84)$ & $3.293^{*}$ \\
\hline
\end{tabular}

Values are presented as mean (SD).

$\mathrm{SLI}=$ children with specific language impairment; $C A=$ chronological age-matched children; LA= language age-matched children.

${ }^{*} p<.05$.

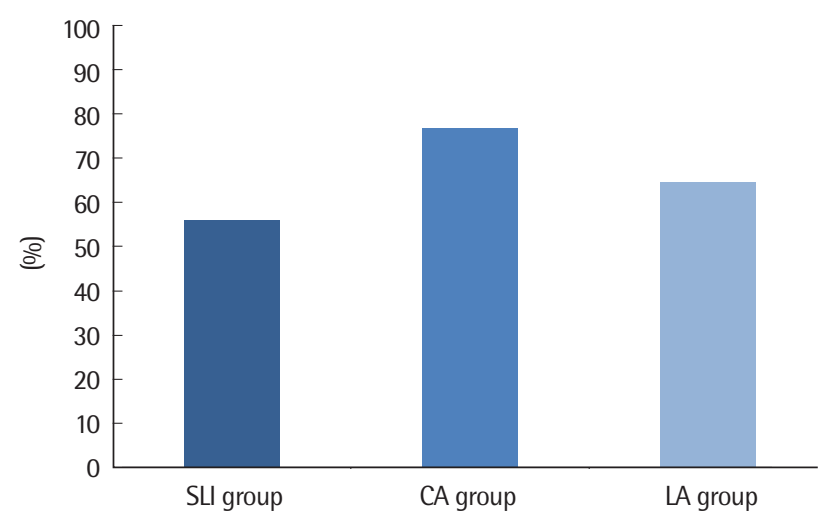

Figure 3. Difference among those groups in the concordance rate of coverbal gesture.

$\mathrm{SLI}=$ children with specific language impairment; $C A=$ chronological agematched children; $L A=$ language age-matched children.

\section{집단 간 구어동반 제스처 일치율}

집단 간 구어동반 제스처 일치율 차이를 비교한 결과, 먼저 단순 언어장애 집단을 살펴보면, 평균 $56.04(\mathrm{SD}=22.34)$ 이었다. 생활연 령일치 집단의 경우, 평균 $76.80(\mathrm{SD}=30.92)$ 이었다. 마지막으로 언 어연령일치 집단을 살펴보면, 평균 $64.62(\mathrm{SD}=30.59)$ 이었다. 요약 하자면, 단순언어장애 집단, 언어연령일치 집단, 생활연령일치 집단 순으로 구어동반 제스처 일치율이 낮았다(Figure 3).

집단 간 구어동반 제스처 일치율의 차이가 유의미한가를 알아보 기 위해 일원분산분석을 실시하였다(Table 4). Table 4에서 제시한 바와 같이 일원분산분석 결과, 집단 간의 차이가 통계적으로 유의 미하지 않았다 $\left(F_{(2,43)}=2.046, p>.05\right)$.

\section{논의 및 결론}

본 연구에서는 무발화 만화 영상을 본 후 이야기를 회상하여 말 하는 과제를 통해 단순언어장애 집단과 일반 아동 집단 간에 제스 처 유형별 산출 빈도의 차이를 확인하고, 세 집단 간 표현양식 유형
Table 4. Comparison of difference among those groups in the concordance rate of coverbal gesture

\begin{tabular}{lcccc}
\hline & $\begin{array}{c}\text { SLI group } \\
(\mathrm{N}=16)\end{array}$ & $\begin{array}{c}\text { CA group } \\
(\mathrm{N}=16)\end{array}$ & $\begin{array}{c}\text { LA group } \\
(\mathrm{N}=16)\end{array}$ & $F$ \\
\hline $\begin{array}{l}\text { Concordance rate of } \\
\text { coverbal gesture }\end{array}$ & $56.04(22.34)$ & $76.80(30.92)$ & $64.62(30.59)$ & 2.046 \\
\hline
\end{tabular}

Values are presented as mean (SD).

$S L I=$ children with specific language impairment; $C A=$ chronological age-matched children; $\mathrm{LA}=$ language age-matched children.

비율의 차이와 구어동반 제스처 일치율의 차이를 비교하여 단순언 어장애아동의 제스처 산출 특성을 살펴보고자 하였다.

첫째, 집단 간 제스처 유형별 산출 빈도를 비교했을 때, 단순언어 장애 집단은 언어연령일치 집단과 마찬가지로 표상적, 지시적, 관습 적 제스처 순이었고, 생활연령일치 집단 역시 표상적 제스처의 빈 도가 가장 높았지만, 지시적 제스처와 관습적 제스처는 동일한 빈 도로 나타났다. 반면, 전체 제스처 총합을 비교했을 때 단순언어장 애 집단은 두 일반 아동 집단보다 높은 빈도의 제스처 산출을 보였 다. 단순언어장애 집단이 높은 빈도의 제스처를 산출하는 것으로 보아 이들이 부족한 표현 언어 능력의 결함을 보충하기 위해 제스 처에 의존한다고 해석할 수도 있을 것이다. 특히, 제스처 유형별 산 출에서도 단순언어장애 아동 집단은 좀 더 나이 어린 언어연령일치 집단과 유사한 산출 경향을 보였지만, 비교적 발달된 형태의 제스 처라고 할 수 있는 표상적 제스처가 가장 높은 빈도로 산출되는 일 반 아동의 산출 경향은 그대로 따르고 있었다. 즉, 단순언어장애 집 단의 제스처 산출에서의 발달적 경향은 두 일반 아동 집단과 크게 다르지 않음을 본 연구를 통해 확인할 수 있었다.

그림 카드로 제스처 표현을 유도하여 지시적 제스처가 표상적 제 스처보다 높았다고 보고한 Lavelli와 Majorano (2016)의 연구와 달 리 본 연구에서는 아동이 무발화 만화 영상을 본 후 이야기를 회상 해서 말하는 동안의 제스처 산출을 분석하였다. 그림 카드나 책과 는 달리 영상은 대상에 대한 정보를 움직이는 시각적 상으로 받아 들이기 때문에 그림 자극과는 다른 기억과 인출 과정이 요구될 것 이다. 본 연구에서 세 집단 모두에서 표상적 제스처가 높은 빈도로 산출된 것은 영상으로 직접 주인공의 움직임이나 대상에 대한 정 보가 이미 노출된 과제의 특성에 영향을 받았을 것으로 해석된다. 즉, 메시지를 형성(formulate)하거나 개념화(conceptualize)하는 데 도움을 주는 수단으로 단어 인출에 도움이 되는 표상적 제스처를 사용한 것으로 해석된다. 반면, 세 집단 모두 매우 낮은 빈도로 관 습적 제스처를 산출하였는데, 아동들이 보인 관습적인 제스처의 대부분은 질문에 대해 ‘모르겠다' 혹은 '생각이 안 난다'를 표현하 
기 위해 ‘고개 젓기', ‘어깨 으쓱하기', 또는 자신의 발화 오류를 수정 하는 '손 가로젓기', '고개 젓기'와 같은 제스처였다. 즉, 무발화 만화 영상의 주인공이나 물체를 지시하거나 행동이나 상태를 관습적 제 스처로 표현하기에는 제한적인 특성이 있기 때문으로 해석된다.

단순언어장애 집단은 표상적 제스처와 더불어 지시적 제스처 역 시 두드러지게 많이 사용하고 있었다. 지시적 제스처는 목표 단어 에 주의를 집중시켜 의미론적 지식을 이끌고(Capone, 2007), 인식 된 대상 또는 행동을 구어로 연결하는 데 도움이 될 수 있다(Stefanini, Recchia \& Caselli, 2008). 제스처는 구어와 함께 발달하는데, 이 때 부족한 어휘 능력을 보충하기 위한 제스처가 중요한 역할을 하기도 한다(Capirci et al., 1996; Thal \& Tobias, 1992). 즉, 언어 표 현 능력이 부족한 아동들의 구어 표현을 대체하거나 보완하는 역 할을 하는 것으로 해석할 수 있으며, 이러한 이유로 어휘 인출의 어 려움을 보이는 단순언어장애 아동들의 지시적 제스처 산출 빈도 가 생활연령일치 집단보다 더 높았을 것으로 해석할 수 있다.

둘째, 집단 간 제스처, 구어, 구어동반 제스처의 표현양식 유형 비 율의 차이를 비교한 결과, 단순언어장애 집단은 구어동반 제스처 가 구어보다 높은 비율로 나타났으나 두 일반 아동 집단은 구어가 가장 높은 비율로 나타났다. 즉, 단순언어장애 아동은 구어 표현의 어려움을 보충하기 위해 제스처에 의존하여 구어동반 제스처 양식 에 대한 선호도가 높았던 반면, 일반 아동은 적절한 표현이 가능하 므로 구어동반 제스처 양식보다 구어 양식을 선호한다는 것으로 해석할 수 있다. 단순언어장애 아동은 구어 표현에 많은 노력이 필 요할 경우 효과적인 의사소통을 하기 위해 가능한 정도의 제스처 를 더 많이 사용한다는 것이다. 이는 구어와 함께 동반되는 제스처 는 언어적 표현이 산출되는 동안에 표현할 개념을 표상하며(Bucci \& Freedman, 1978), 제스처가 어휘 찾기를 지원한다는 주장(Kendon, 2004)에 의해 지지될 수 있다. 따라서 구어와 함께 제스처를 사용하는 것은 단순언어장애 아동의 언어 능력을 향상시키기 위한 효과적인 중재 전략이 될 수도 있을 것이다. 그러므로 본 연구의 이 러한 결과는 단순언어장애 아동 가운데 구어동반 제스처가 아동 이 선호하는 표현 전략임이 평가 과정을 통해 확인이 된다면 아동 이 충분히 제스처를 사용할 수 있도록 촉진하여 구어와 제스처를 함께 사용했을 때 성공적인 의사소통을 할 수 있음을 인지시킴으 로써 아동 스스로 이를 자신의 소통 전략으로 활용할 수 있도록 중 재가 계획될 수 있어야함을 시사한다.

마지막으로, 아동이 구어로 표현한 정보와 제스처로 표현한 정 보가 일치하는지와 관련해 집단 간 구어동반 제스처 일치율의 차 이를 살펴본 결과에서는 단순언어장애 아동이 일반 아동보다 높 은 빈도로 제스처를 산출하였으나 구어동반 제스처 일치율의 차이
는 없는 것으로 나타났다. 이러한 결과는 단순언어장애 아동의 제 스처와 구어를 조합하여 사용하는 능력이 일반 아동과다르지 않다 는 것으로 해석할 수 있다. 본 연구의 이러한 결과는 Mainela-Arnold 등(2014)의 연구에서도 확인된 바가 있다. 이들은 생활 연령 5-10세의 단순언어장애 아동과 일반 아동이 90 초 길이의 무발화 만화 영상을 보고 이야기 내용에 익숙하지 않은 청자에게 이야기 를 다시 말하는 동안에 산출한 구어-제스처 조합에서 구어로 전달 한 정보와 제스처로 전달한 정보가 일치하는 경우를 분석함으로 써 일치율의 차이를 살펴보았다. 이들은 단순언어장애 아동들이 일반 아동보다 더 많은 제스처를 산출하였지만 구어와 제스처 조 합이 일치하지 않을 가능성은 일반 아동과 크게 다르지 않다고 보 고하였다. 즉, 단순언어장애 아동들이 구어와 제스처를 조합하여 사용하는 능력에서 일반 아동과 비교적 차이가 없으므로 구어동 반 제스처 양식을 선호하는 단순언어장애 아동이 설명하기 과제와 같이 인지적 부담이 높은 과제 수행에서 의도 표현을 위해 구어와 제스처를 활용하도록 촉진하여 중재에 적용한다면 이들의 언어 능 력을 효율적으로 향상시킬 수 있을 것이다.

제스처는 말로 산출하는 단어나 의미관계 표현들과 마찬가지로 어린 아기들이 알고 있는 것을 반영하므로 언어 이전 단계부터 성 인과 아동 간의 소통에서 많은 의미와 화용적 기능을 제공한다 (Singleton \& Shulman, 2020). 본 연구에서는 무발화 만화 영상을 본 후 회상하는 과제에서 단순언어장애 아동이 보이는 구어동반 제스처 일치율 차이와 제스처 유형별 산출 빈도에 더해, 기존 연구 들이 살펴보지 않았던 표현양식 유형까지 살펴보았다는 데 연구 의 의가 있다. 특히, 연구 결과를 통해 단순언어장애 아동이 부족한 구 어 표현을 보상하기 위해 더 많은 제스처를 사용하며, 일반 아동과 비교해 구어동반 제스처라는 표현양식의 사용이 구어보다 높았음 을 확인할 수 있었다. 즉, 단순언어장애 아동이 표현하는 구어동반 제스처 일치율이 일반 아동과 비교해 큰 차이가 없다는 것을 밝힘 으로써, 이들이 대화 상대방과의 의사소통을 보다 효율적으로 이 끌기 위해 적극적으로 노력을 기울이는 언어 수행(linguistic performance)을 통해 융통성을 발휘할 수 있는 화자임을 확인할 수 있 었다. 따라서, 단순언어장애 아동들이 초기 표현 언어 단계에서 다 양한 의미 기능을 표현할 수 있도록 언어 중재 과정에서도 제스처 사용을 촉진하여 부족한 구어 의사소통을 지원할 수 있을 것이다.

다만, 본 연구에서 사용된 무발화 만화 영상은 독일의 어린이 만 화인 'Die Sendung mit der Maus (생쥐와 함께 하는 프로그램)'의 시리즈 중에서 선정한 에피소드로 독일 아동에게는 매우 친숙한 내용의 영상이지만 우리나라 아동에게는 비교적 친숙한 등장인물 들이 아니므로 친숙도면에서는 아동의 발화산출에 간접적으로 영 
향이 있었을 것으로 보여진다. 그러므로 후속 연구에서는 우리나 라 아동에게 좀더 친숙한 내용의 영상을 선정하여 제스처 산출특 성을 살펴볼 필요성이 있을 것이다. 또한, 본 연구의 연구 절차와 관 련하여 아동의 모습을 더 자세하게 녹화하기 위한 카메라 수와 카 메라 위치 선정에 한계가 있었던 것으로 보인다. 좀 더 다양한 각도 에서의 녹화를 위해 카메라의 수와 카메라 설치 위치를 고려할 필 요가 있었을 것으로 보인다.

후속 연구와 관련해 본 연구에서 사용한 무발화 만화 영상은 움 직이는 시각 정보로 입력이 제공되어 아동의 집중도 향상과 흥미 를 이끄는 데 기여한 바가 있었을 것이다. 따라서, 선행연구들에서 사용된 여러 가지 제스처 표현을 위한 자료 수집 상황에 따른 제스 처 유형이나 빈도에 대한 직접적인 비교 역시 매우 흥미 있는 연구 주제가 될 것으로 보여진다. 즉 청각적, 시각적으로 주어지는 자극 입력에 따라 제스처 유형별 산출의 차이를 비교해볼 수 있을 것이 다. 특히, 자유놀이, 그림이나 책, 영상 등의 다양한 상황에서 나타 나는 아동의 제스처 산출 특성을 비교하여 살펴보는 것도 의미가 있을 것이다.

\section{REFERENCES}

Acredolo, L., \& Coodwyn, S. (1996). Baby signs: How to talk to your baby before your baby can talk. Chicago, IL: NTB/Contemporary.

Alibali, M. W., Evans, J. L., Hostetter, A. B., Ryan, K., \& Mainela-Arnold, E. (2009). Gesture-speech integration in narrative: are children less redundant than adults?. Gesture, 9(3), 290-311.

An, S. J. (2010). The change in the ratio of gesture utilization in children's grammar formation phase: focusing on iconic gesture (Master's thesis). Ewha Womans University, Seoul, Korea.

An, S. J., Bang, H. J., \& Lee, S. H. (2010). The change in the ratio of gesture utilization in 2-3 years old children: focusing on iconic gestures. Korean Journal of Developmental Psychology, 23(1), 33-50.

Bangerter, A. (2004). Using pointing and describing to achieve joint focus of attention in dialogue. Psychological Science, 15(6), 415-419.

Blake, J., Myszczyszyn, D., Jokel, A., \& Bebiroglu, N. (2008). Gestures accompanying speech in specifically language-impaired children and their timing with speech. First Language, 28(2), 237-253.

Bucci, W., \& Freedman, N. (1978). Language and hand: the dimension of referential competence 1. Journal of Personality, 46(4), 594-622.

Capirci, O., Iverson, J. M., Pizzuto, E., \& Volterra, V. (1996). Gestures and words during the transition to two-word speech. Journal of Child Language,
23(3), 645-673.

Capone, N. (2007). Tapping toddlers' evolving semantic representation via gesture. Journal of Speech, Language, and Hearing Research, 50(3), 732-745.

De Ruiter, J. P. (2006). Can gesticulation help aphasic people speak, or rather, communicate?. Advances in Speech Language Pathology, 8(2), 124-127.

Esseily, R., Jacquet, A., \& Fagard, J. (2011). Handedness for grasping objects and pointing and the development of language in 14-month-old infants. Laterality, 16(5), 565-585.

Evans, J. L., Alibali, M. W., \& McNeil, N. M. (2001). Divergence of embodied knowledge and verbal expression: evidence from gesture and speech in children with specific language impairment. Language and Cognitive Processes, 16(2), 309-331.

Guidetti, M., \& Colletta, J. M. (2010). Gesture and multimodal development. Gesture, 10(2), 123-128.

Hadar, U., \& Pinchas-Zamir, L. (2004). The semantic specificity of gesture: implications for gesture classification and function. Journal of Language and Social Psychology, 23(2), 204-214.

Iverson, J. M., Capirci, O., Longobardi, E., \& Caselli, M. C. (1999). Gesturing in mother-child interactions. Cognitive Development, 14(1), 57-75.

Kendon, A. (2004). Gesture: visible action as utterance (H. K. Kim, Y. R. Shin, J. Y. Song, \& H. S. Kim, Trans.). UK: Cambridge University Press.

Kim, E. H. (2006). The relationship between the communicative gesture and the vocabulary acquisition of infants. (Doctoral dissertation). Yonsei University, Seoul, Korea.

Kim, E. H., \& Kim, M. S. (2006). The relationship between the communicative gesture and the vocabulary acquisition of infants. Korean Journal of Child Studies, 27(6), 217-234

Kim, S. H., \& Ko, D. H. (2002). The use of gestures in one-word level children with down syndrome. Korean Journal of Communication \& Disorders, 7(3), 95-106.

Kim, Y. T. (2014). Assessment and treatment of language disorders in Children. Seoul: Hakjisa.

Kim, Y. T., Sung, T. J., \& Lee, Y. K. (2003). Preschool receptive-expressive language scale (PRES). Seoul: Seoul Community Rehabilitation Center.

Lavelli, M., Barachetti, C., \& Florit, E. (2015). Gesture and speech during shared book reading with preschoolers with specific language impairment. Journal of Child Language, 42(6), 1191-1218.

Lavelli, M., \& Majorano, M. (2016). Spontaneous gesture production and lexical abilities in children with specific language impairment in a naming task. Journal of Speech, Language, and Hearing Research, 59(4), 784-796. 
Lee, S., \& Lee, H. (2012). The astonishing language development of children. Seoul: Hakjisa.

Lee, Y., Jeon, J. A., \& Lee, J. Y. (2014). Communicative gestures of toddlers who are at risk autism spectrum disorder and developmental language delay. Journal of the Korean Association for Persons with Autism, 14(3), 17-33.

Lee, Y., \& Lee, H. (2015). Communicative gestures in toddlers with developmental language delay and their relations to language development. Communication Sciences \& Disorders, 20(2), 255-265.

Leonard, L. B. (2014). Children with specific language impairment (2nd Eds.). Cambridge, MA: MIT Press.

Lozano, S. C., \& Tversky, B. (2006). RETRACTED: communicative gestures facilitate problem solving for both communicators and recipients. Journal of Memory and Language, 55(1), 47-63.

Lueke, C., Ritterfeld, U., Grimminger, A., Liszkowski, U., \& Rohlfing, K. J. (2017). Development of pointing gestures in children with typical and delayed language acquisition. Journal of Speech, Language, and Hearing Research, 60(11), 3185-3197.

Mainela-Arnold, E., Alibali, M. W., Hostetter, A. B., \& Evans, J. L. (2014). Gesture-speech integration in children with specific language impairment. International Journal of Language \& Communication Disorders, 49(6), 761770.

McNeill, D. (1998). Speech and gesture integration. In J. M. Iverson and S. Goldin-Meadow (Eds.), The nature and function of gesture in children's communications (pp. 11-28). San Francisco: Jossey-Bass.

Moon, S. B., \& Byun, C. J. (2003). Korean Kaufman assessment battery for children (K-ABC). Seoul: Hakjisa.

Morford, M., \& Goldin-Meadow, S. (1992). Comprehension and production of gesture in combination with speech in one-word speakers. Journal of Child Language, 19(3), 559-580.

Pae, S. Y., \& Kwak, K. J. (2011). Korean MacArthur-Bates Communicative Development Inventory (K M-B CDI). Seoul: Mind Press.

Park, S. J. (2009). The relationship among gesture and the vocabulary of infants: focusing on 8-24 months infant (Master's thesis). Ewha Womans University, Seoul, Korea.
Ryu, J., \& Yu, J. (2013). The impact of gesture and facial expression on learning comprehension and persona effect of pedagogical agent. Korean Journal of the Science of Emotion \& Sensibility, 16(3), 281-292.

Shin, A. S., \& Kim, Y. S. (2016). Longitudinal study on vocabulary development of infants aged 10 to 18 months: centering on infants' communicative gestures and temperament. Korean Journal of Early Childhood Education, 36(1), 273-295.

Singleton, N. C., \& Shulman, B. B. (2020). Language development: foundations, processes, and clinical applications. Burlington, MA: Jones \& Bartlett Learning.

So, W. C., Wong, M. K. Y., Lui, M., \& Yip, V. (2015). The development of cospeech gesture and its semantic integration with speech in 6-to 12-yearold children with autism spectrum disorders. Autism, 19(8), 956-968.

Stefanini, S., Recchia, M., \& Caselli, M. C. (2008). The relationship between spontaneous gesture production and spoken lexical ability in children with Down syndrome in a naming task. Gesture, 8(2), 197-218.

Thal, D. J., \& Tobias, S. (1992). Communicative gestures in children with delayed onset of oral expressive vocabulary. Journal of Speech, Language, and Hearing Research, 35(6), 1281-1289.

Van der Sluis, I., \& Krahmer, E. (2007). Generating multimodal references. Discourse Processes, 44(3), 145-174.

Weismer, S. E., \& Hesketh, L. J. (1993). The influence of prosodic and gestural cues on novel word acquisition by children with specific language impairment. Journal of Speech, Language, and Hearing Research, 36(5), 10131025.

Wetherby, A. M., \& Prizant, B. M. (2002). CSBS DP manual: Communication and Symbolic Behavior Scales Developmental Profile (CSBS DP). Baltimore, MD: Paul H. Brookes Publishing.

Wetherby, A. M., \& Prutting, C. A. (1984). Profiles of communicative and cognitive-social abilities in autistic children. Journal of Speech, Language, and Hearing Research, 27(3), 364-377.

Wetherby, A., \& Prizant, B. (1989). The expression of communicative intent: assessment guidelines. Seminars in Speech and Language, 10(1), 77-91. 

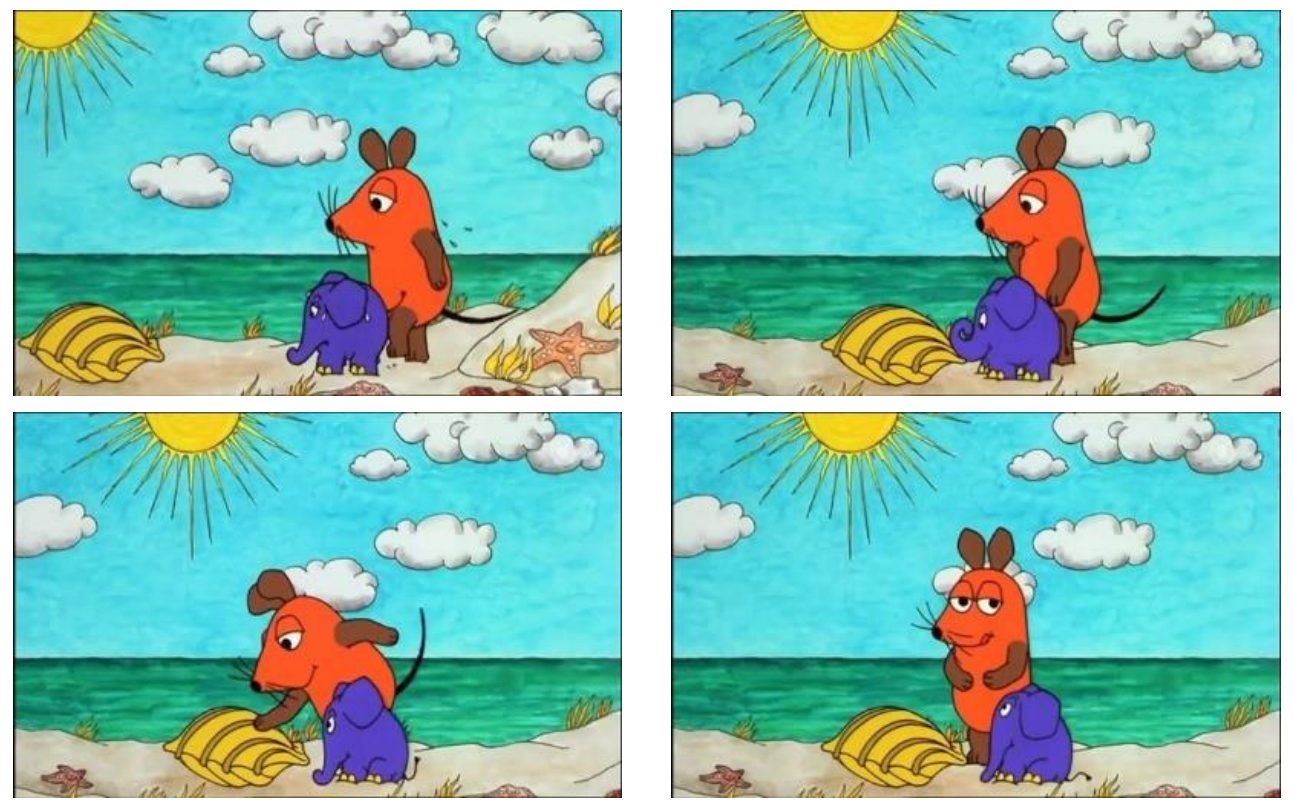

(중략)
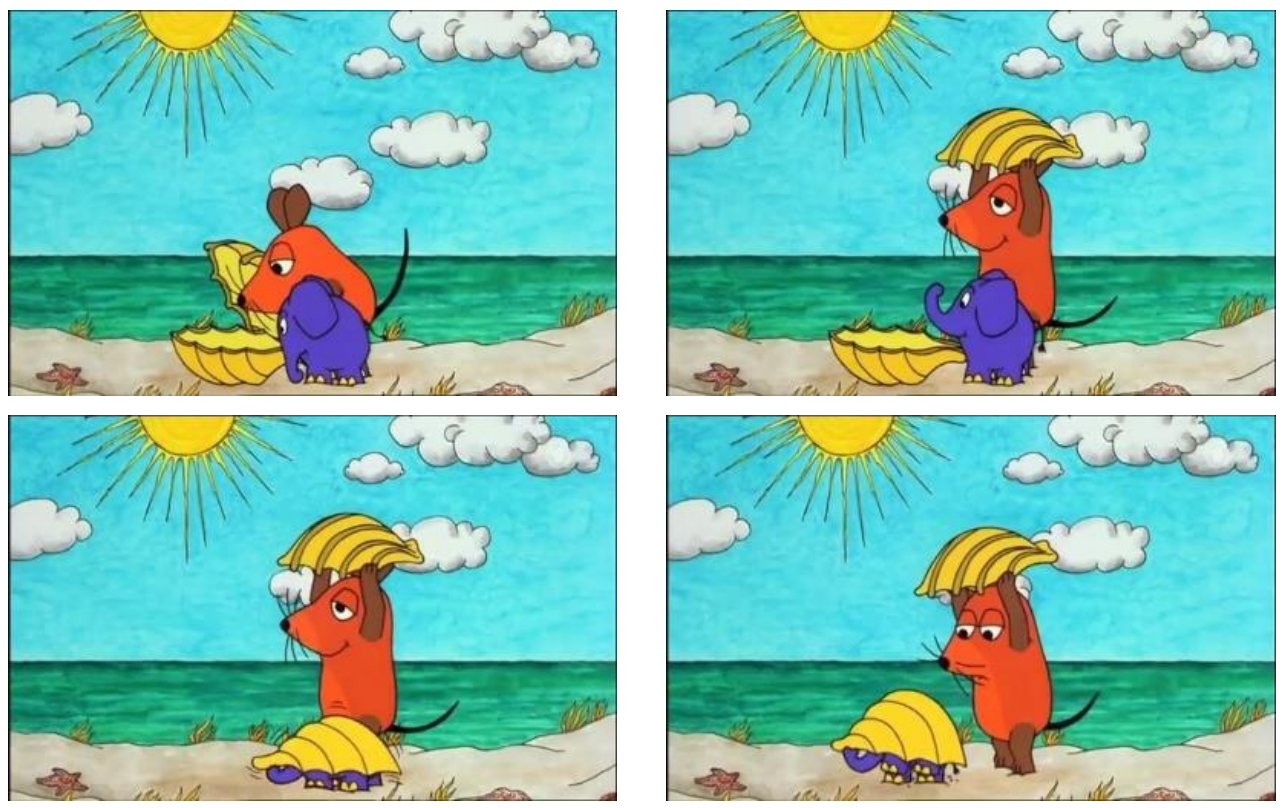
Appendix 2. Facilitative questions

\begin{tabular}{ll}
\hline 문항 & \multicolumn{1}{c}{ 질문 내용 } \\
\hline 1 & 처음에 쥐랑 코끼리가 바닷가를 어떻게 걸었는지 조금 더 자세하게 이야기해 줄래? \\
2 & 쥐가 조개를 열려고 어떻게 했는지 조금 더 자세하게 이야기해 줄래? \\
3 & 코끼리가 조개를 어떻게 열었는지 조금 더 자세하게 이야기해 줄래? \\
4 & 쥐가 조개를 쓴 모습을 조금 더 자세하게 이야기해 줄래? \\
5 & 코끼리가 조개를 쓴 모습을 조금 더 자세하게 이야기해 줄래? \\
\hline
\end{tabular}

Appendix 3. Operational definition and example of each gesture type

\begin{tabular}{|c|c|c|}
\hline 유형 & 조작적 정의 & 예시 \\
\hline 지시적 제스처 & $\begin{array}{l}\text { 사물 또는 사건이 존재하거나 존재하지 않을 때 주의를 끌거나 } \\
\text { 지시하는 행동 }\end{array}$ & 만화에 등장하는 조개를 지시하기 위해 손가락으로 가리키기 \\
\hline 관습적 제스처 & 형태와 의미가 문화적(일상적)으로 정의된 행동 & 이야기 내용이 기억나지 않음을 표현하기 위해 고개를 젓기 \\
\hline 표상적 제스처 & $\begin{array}{l}\text { 특정 대상의 성질(모양, 상태)이나 행동을 상징적으로 표현하는 } \\
\text { 제스처 }\end{array}$ & $\begin{array}{l}\text { 조개를 표현하기 위해 손으로 둥근 형태의 모양을 만들거나 } \\
\text { 양 손바닥을 붙였다 떼었다 하기 }\end{array}$ \\
\hline
\end{tabular}




\section{국문초록}

이야기 회상 과제에서 나타난 학령전 단순언어장애 아동의 제스처 산출 특성 김은영 · 이희란

부산가톨릭대학교 언어청각치료학과

배경 및 목적: 본 연구에서는 무발화 만화 영상을 본 후 이야기를 회상하여 말하는 동안 산출하는 제스처를 통해 단순언어장애 아동 과 일반 아동의 제스처 유형별 산출 빈도, 표현양식 유형 비율, 구어동반제스처 일치율을 비교하였다. 방법: 본 연구의 대상은 5-6세 단 순언어장애 아동 16 명, 단순언어장애 아동과 생활연령을 일치시킨 일반 아동 16 명, 언어연령을 일치시킨 일반 아동 16 명이었다. 제스처 산출특성을 살펴보기 위해 무발화 만화영상과 촉진질문 5 개를 제시하였다. 결과: 단순언어장애 집단은 일반아동 집단보다 지시적, 표 상적 제스처 산출 빈도가 높았으며 구어동반제스처의 비율이 가장 높게 나타났다. 구어동반제스처 일치율의 차이는 없었다. 논의 및 결론: 본 연구에서 단순언어장애 집단은 일반 아동 집단보다 높은 제스처 산출 빈도를 보였으며 구어동반제스처의 비율이 가장 높게 나타났다. 하지만 구어동반제스처 일치율의 차이는 없는 것을 확인하였다. 이는 단순언어장애 아동들이 구어와 제스처를 조합하여 사 용하는 능력에서 일반 아동과 비교적 차이가 없으므로 단순언어장애 아동의 표현 언어 능력을 효율적으로 향상시키기 위해 구어와 제 스처를 함께사용하도록 중재가 필요하다는 것을 시사한다

핵심어: 단순언어장애, 제스처, 구어동반 제스처

본 연구는 제1저자의 석사학위논문을 수정하여 작성하였음.

\section{참고문헌}

Kendon, A. (2004). 제스처: 소통을 위한 인간의 몸짓(김현강, 신유리, 송재영, 김하수 역). 서울: 박이정. 김선해, 고도흥 (2002). 한낱말 단계 다운증후군아동의 제스츄어 사용. 언어청각장애연구, 7(3), 95-106. 김영태 (2014). 아동언어장애의 진단 및 치료. 서울: 학지사.

김영태, 성태제, 이윤경 (2003). 취학 전 아동의 수용언어 및 표현언어 발달 척도(PRES). 서울: 서울장애인종합복지관. 김의향 (2006). 7-24개월 영아의 의사소통적 몸짓과 어휘습득 간의 관계. 연세대학교 대학원 박사학위논문. 김의향, 김명순 (2006). 7-24개월 영아의 의사소통적 몸짓과 어휘 습득 간의 관계. 아동학회지, 27(6), 217-234. 류지헌, 유지희 (2013). 학습용 에이전트의 제스처와 얼굴표정이 학습이해도 및 의인화 효과에 미치는 영향. 감성과학, 16(3), 281-292. 문수백, 변창진 (2003). K-ABC 교육 - 심리측정도구(Korean-Kaufman assessment battery for children). 서울: 학지사. 박세진 (2009). 영아의 몸짓 사용 종류와 어휘 습득 간의 관계: 8-24개월 영아를 중심으로. 이화여자대학교 대학원 석사학위논문. 배소영, 곽금주 (2011). 한국판 맥아더-베이츠 의사소통발달평가(K M-B CDI). 서울: 마인드프레스. 신애선, 김영실 (2016). 10-18개월 영아 어휘력 발달의 종단연구: 영아의 의사소통적 몸짓과 기질을 중심으로. 유아교육연구, 36(1), 273-295. 안소정 (2010). 문법형성단계 아동의 세부 몸짓 사용 비율의 변화: 참조적 몸짓을 중심으로. 이화여자대학교 대학원 석사학위논문. 안소정, 방희정, 이순행 (2010). 문법형성단계 2-3세 아동의 세부 몸짓 사용 비율의 변화. 한국심리학회지: 발달, 23(1), 33-50. 이승복, 이희란 (2012). 아이와함께 하는 신기한 언어발달. 서울: 학지사. 이윤경, 이효주 (2015). 언어발달지체 영아의 의사소통적 제스처 특성과 언어발달과의 관계. Communication Sciences \& Disorders, 20(2), 255-265. 이윤경, 전진아, 이지영 (2014). 자폐범주성장애 위험 영아와 언어발달지체 영아의 의사소통적 제스처 사용 비교. 자폐성장애연구, 14(3), 17-33.

\section{ORCID}

김은영(제1저자, 언어재활사 https://orcid.org/0000-0002-3875-724X); 이희란(교신저자, 교수 https://orcid.org/0000-0002-7898-4623) 